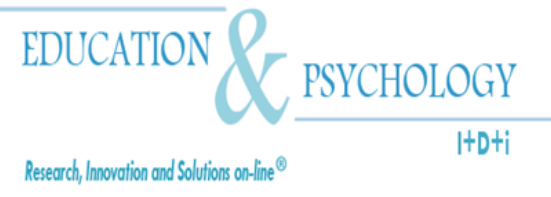

\title{
Identifying Predictors of Secondary School Perfomance In Agricultural Science In Nigeria
}

\section{Olowa Olatomide Waheed}

Department of Agricultural Education

Federal College of Education (Tech.) Lagos

Nigeria

Correspondence: Olowa Olatomide Waheed. Department of Agricultural Education. Federal College of Education (Tech.). Akoka. Lagos. Nigeria. olowa1@yahoo.com

(C) Education \& Psychology I+D+i and Editorial EOS (Spain) 


\begin{abstract}
Introduction. Increasing Awareness of the importance of vocational agricultural education has driven various regimes in government and Educators to embark on several review of agricultural curriculum at both secondary and tertiary institutions and as well provided policies and incentives towards motivating young ones to study and take agriculture as a good and profitable way of life when properly practiced. Unfortunately, in spite of various efforts by the government and other stake holders, it had been widely reported that agriculture in schools had been a failure. Evaluation and student performance, which is the focus of this study is one of the components of school's agricultural programmes in Nigeria. Various variables has been implicated to be related to academic performance but the literatures are not consistent as to which of these variables can be classified as main independent variables or rival independent variable.
\end{abstract}

Method. Schools in Ondo State (Nigeria) constituted the sample for the study. Scores in the sample agriculture examination taken by all students in 2007 as well as data collected through the use of researcher developed instruments were analyzed as a group since analysis of variance showed no significant differences between schools.

Results. These showed that overall grade and integrated science (physics, chemistry and Biology) were significant at 0.05 probalities. The two variables explained $67 \%$ of the variance in agricultural secondary school student performance. Mathematics grade though was not found to be the best predictor, but had a high correlation $(0.63)$ with the dependent variable.

Conclussion. Overall grade, integrated science and mathematics are to be given prominence in the requirement for admission into further studies in agriculture.

Keywords: Predictors, Nigeria, Agriculture, Secondary School, Science Performance.

Received: 11/25/08 Initial Acceptance: 03/28/09 Definitive Acceptance: 09/08/09 


\section{La identificación de predictores del rendimiento durante la Educación Secundaria, en Ciencias Agrícolas en Nigeria}

\section{Resumen}

Introducción. La creciente conciencia sobre la importacia de la educación agraria ha dirigido a varios gobiernos y educadores a la revisión del currículum agrícola tanto en secundaria como en niveles superiores así como a proporcionar políticas e incentivos dirigidos a motivar a los jóvenes a estudiar y tener en consideración la agricultura como una alternativa beneficiosa. Desafortunadamente, y a pesar de los esfuerzos gubernamentales, la asignatura en agricultura ha sido un fracaso. La evaluación y el rendimiento del alumnado en los programas de agricultura en Nigeria son los objetivos de este estudio. Varias variables han relacionadas con el rendimiento del alumnado aunque los estudios no son consistentes.

Método. Escuela del estado de Ondo (Nigeria) constituyen la muestra del estudio. Se ha tomado información de la evaluación del alumnado durante el curso académico 2007 así como otros datos recogidos mediante instrumentos desarrollados por el investigador. Los análisis de la varianza no indican diferencias significativas entre los centros estudiados.

Resultados. Los resultados señalan que los cursos en global y las ciencias integradas (física, química y biología) eran significativas al 0.05. Las dos varialbes estudiadas explican el 67\% de la varianza en la ejecución del estudiante en secundaria. Las matemáticas no se muestran como el mejor predictor aunque presentan una correlación alta $(0.63)$ con la variable dependiente.

Conclusión. El curso en general, las ciencias integradas y las matemáticas deben tener más prominencia como requisitos previos para la admisión en los estudios de agricultura.

Palabras Clave: Predictores, Nigeria, Agricultura, Educación Secundaria, Redimiento. Recibido: 25/11/08 Aceptación inicial: 28/03/09 Aceptación final: 08/09/09 


\section{Introduction}

Agriculture remains an important sector of the Nigerian Economy since it has a high potential for absorbing unemployed and underemployed persons and at the same time generate foreign exchange for the country. It was in realization of this that the Nigerian governments (present and past) have encouraged the teaching of Agriculture to primary and secondary school pupils to give knowledge background, which equips them to become interested in agriculture as a source of livelihood.

Formal Agricultural education in Nigeria started with such schools as St. Joseph's Agricultural School in Topo, the Wesleyan High School (established in 1848) and the Hope Waddel Institute (1859), having some form of agricultural education on their curriculum. At primary school level agricultural curriculum during this period was grossly restricted to the production of crops sufficient to feed the teachers and the pupils; and there were no incentives capable of motivating anybody to take up agriculture as a means of livelihood.

Increasing awareness of the important of vocational agricultural education has driven various regimes in government and Educators to embark on several review of agricultural curriculum at both secondary and tertiary institutions and as well provided policies and incentives towards motivating young ones to study and engage in agricultural policies. Unfortunately, inspite of various efforts by the government and other stakeholders, it has been widely reported that agricultural in schools had been a failure (Gooday, 1974; Olowa, 2002; Oluwole, 1985) due to the following factors:

- $\quad$ Agriculture curriculum was not geared towards scientific large scale production.

- $\quad$ There were few qualified teachers.

- Instructional materials were either non-existent or imported from areas where physical and economic conditions were very different.

- Using practical work as a means of punishing students.

- $\quad$ There was minimal administrative supervision.

- $\quad$ Poor funding.

Presently in Nigeria, pupils are expected to take agricultural science the first three years in secondary school. Agriculture at senior secondary is optional for student; suffice it to 
say that evaluation and student performance, which is what this study is addressing, is one of the components of school's agricultural programme in Nigeria numerous literatures (Blustein, 1986; Dispensieri, 1971; Duke and Duke, 1990; Godwin, 1990; Larose and Roland, 1991; Ojelade, 2004; Olowa, 2002; Oluwole, 1985), has implicated various variables are related to academic performance. They can be classified as: school related variables (time spent studying, sharing of room, times spent in the library, interest in the programme being pursued, distance of home from school, number of times a student visits home in a month; academic performance in Maths, Agriculture, English and overall grade); home/background related variables (Educational level of father, mother, family income, access to land by family); and finally, individual student-related variables (age, drinking habits, years living away from parents). The literature was not consistent as to which of these variables, can be classified as main independent variables which is the gap in knowledge this paper is set to bridge.

\section{Objectives of the Study}

The study was designed to achieve the following objectives:

1. To describe Ondo State agricultural students on selected home and school related variables.

2. To describe the relationship between performance in agriculture of Ondo State Secondary School students and each of the selected home and school related variables.

3. To identify the predictors of Ondo state Secondary School Students' Performance in agriculture from the selected home and school related variables.

\section{Method}

\section{Participants}

The population for the study comprised of all students offering agriculture science in Ondo State Secondary Schools. Ondo State is situated in Western rain-forest part of Nigeria and is one of the highly rated states in terms of Education in Nigeria. For the purpose of this study, the state was divided into four educational zones namely: Akure, Ondo, Ikale and Ilaje zones. Two schools each were purposefully selected from the four (4) zonal education divisions of the state, totaling Eight Schools. These Schools were the top four private secondary 
schools plus four other public secondary schools The sample frame consisted of two Hundred (200)Secondary School Agriculture Students who had intact academic record(Agricultural science students were few in the four private schools). The classes were identified through the agricultural science teachers in these schools during the 2006/2007 academic year. The lists of classes and students were screened to avoid duplications, and thus, control selection error. The number of participating students (200) was determined through a stratified sampling method but using an intact class for each stratum (Description of participants on age, sex and other characteristics are elucidated in Table 1-Home and school related characteristics of Students). This sampling process was conducted to control sampling error.

\section{Instrument}

Data on the dependent variable (Students' Performance in Agriculture) were scores on the sample agriculture examination taken by all students during the year 2007. Content validity for the examination was established and attested by a panel of experts. A researcherdeveloped-instrument, personally administered on the sport, was used to collect data on the home and school related variables (Independent Variable). These variables included: age, gender, residential area, educational level of parents (father and mother), land-size owned by family (ha), students' interest in agriculture, students' performance in mathematics, integrated science, and overall performance.

\section{Procedure}

The study was partly a descriptive survey and party correlation in nature. It was a survey because opinion of students on the home and school related variables were surveyed. It was also correlational because the study sought to determine the degree of association between performance in agriculture by secondary school students and the school related variables.

\section{Statistical Analysis}

Data were analyzed as a group, since analysis of variance showed no significant difference between schools. Frequencies, means, standard deviations, correlations, and multiple regression coefficients were used to analyze data for this study. The alpha level was set a priori at 0.05 . 


\section{Results}

Table 1 shows the summary of predictor variables for this study. Descriptive statistics of minimum and maximum values for each variable, mean, standard deviation, and the unit of measurement for each selected independent variable were also indicated. Student interest in Agriculture was measured by Likert scale which consisted of a set of six points and ranges from extremely uninterested, very uninterested, uninterested, interested, very interested, to extremely interested.

Table 1. Home and School Related Characteristics of Students.

\begin{tabular}{|c|c|c|c|c|c|c|}
\hline & Variables & Mean & $\begin{array}{l}\text { Standard } \\
\text { Deviation }\end{array}$ & $\begin{array}{l}\text { Maximum } \\
\text { Value }\end{array}$ & $\begin{array}{l}\text { Minimum } \\
\text { Value }\end{array}$ & $\begin{array}{c}\text { Unit of } \\
\text { Measurement }\end{array}$ \\
\hline 1 & Age & 5.67 & 1.53 & 19 & 11 & Years \\
\hline 2 & Gender & 0.50 & 0.48 & 1 & 0 & Category $^{\text {a }}$ \\
\hline 3 & Residential Area & 0.85 & 0.58 & 1 & 0 & Category ${ }^{b}$ \\
\hline 4 & Educ. Level of father & 7.89 & 3.30 & 17 & 1 & Years \\
\hline 5 & Land size of family & 4.05 & 6.00 & 65 & 0 & Hectares \\
\hline 6 & $\begin{array}{l}\text { Family revenue from } \\
\text { agricultura }\end{array}$ & 956.08 & 6.000 & 50.000 & 0 & Naira \\
\hline 7 & Educ. Level of mother & 7.33 & 3.54 & 17 & 0 & Years \\
\hline 8 & Interest in Agriculture & 5.56 & 1.02 & 6 & 1 & Likert Scale \\
\hline 9 & Maths Score & 19.07 & 21.00 & 96 & 0 & Percentage \\
\hline 10 & Overall Grade & 19.31 & 1.61 & 88 & 0 & Percentage \\
\hline 11 & Science Score & 15.45 & 19.31 & 94 & 0 & Percentage \\
\hline 12 & Agriculture Score & 15.98 & 19.20 & 95 & 0 & Percentage \\
\hline
\end{tabular}

To describe the relationship between performance in agriculture of secondary school students and each of the homes and school related variables, correlations were generated. To describe the magnitude of relationships, Davis (1971) scale of descriptors as adopted by Dlamini (1995) was used. The results were presented in Table 2.

Table 3 reveals very strong associations between performance in agriculture by secondary school students and the following variables; student overall score $(\mathrm{r}=0.80)$ and student science score $(\mathrm{r}=0.76)$. The result further revealed substantial associations between performance in agriculture by secondary school students and student score in mathematics $(r=0.63)$. The rest of the independent variables indicated negligible to low association with the dependent variable, performance in agriculture by secondary school. 
Table 2. Intercorrelations among Home, and school Related Characteristics and Performance of Secondary School Students in Agriculture.

\begin{tabular}{|c|c|c|c|c|c|c|c|c|c|c|c|c|}
\hline & Variable & DV & $\mathbf{V}^{1}$ & $\mathbf{V}^{2}$ & $\mathbf{V}^{3}$ & $\mathbf{V}^{4}$ & $\mathbf{V}^{5}$ & $V^{6}$ & $\mathbf{V}^{7}$ & $\mathbf{V}^{8}$ & $\mathbf{V}^{9}$ & $V^{10}$ \\
\hline $\mathrm{V}^{1}$ & Age & -12 & & & & & & & & & & \\
\hline $\mathrm{V}^{2}$ & Gender & 0.02 & 0.19 & & & & & & & & & \\
\hline $\mathrm{V}^{3}$ & Residential Area & 0.06 & -0.21 & 0.05 & & & & & & & & \\
\hline $\mathrm{V}^{4}$ & $\begin{array}{l}\text { Educ. Level of } \\
\text { father }\end{array}$ & 11 & -0.15 & 0.14 & 0.13 & & & & & & & \\
\hline $\mathrm{V}^{5}$ & $\begin{array}{l}\text { Land size of fa- } \\
\text { mily }\end{array}$ & 0.09 & 0.04 & 0.03 & 0.10 & 0.08 & & & & & & \\
\hline $\mathrm{V}^{6}$ & $\begin{array}{l}\text { Agriculture Re- } \\
\text { venue }\end{array}$ & -0.01 & -0.09 & 0.13 & 0.10 & 0.09 & 0.19 & & & & & \\
\hline $\mathrm{V}^{7}$ & $\begin{array}{l}\text { Educ. Level of } \\
\text { mother }\end{array}$ & 0.06 & -0.23 & 0.19 & 0.13 & 0.08 & 0.04 & 0.06 & & & & \\
\hline $\mathrm{V}^{8}$ & $\begin{array}{l}\text { Agriculture inter- } \\
\text { est }\end{array}$ & 0.08 & 0.09 & 0.17 & 0.15 & 0.09 & -0.02 & 0.23 & 0.02 & & & \\
\hline $\mathrm{V}^{9}$ & Maths Score & 0.63 & -0.08 & 0.04 & 0.08 & 0.09 & -0.12 & 0.04 & 0.07 & 0.11 & & \\
\hline $\mathrm{V}^{10}$ & Overall Score & 0.80 & -0.19 & 0.03 & 0.08 & 0.14 & 0.02 & $-\overline{0}$ & 0.12 & 0.08 & 0.79 & \\
\hline $\mathrm{V}^{11}$ & Science Score & 0.76 & -0.18 & 0.09 & 0.07 & 0.06 & 0.08 & 0.08 & 0.04 & 0.04 & 0.72 & 0.80 \\
\hline
\end{tabular}

Table 3. Predictor of Students' Performance in Secondary School Agriculture (N=200).

\begin{tabular}{|c|c|c|c|c|c|c|c|}
\hline \multicolumn{8}{|c|}{ Dependent Variable; Performance of Students in Secondary School Agriculture } \\
\hline & $\mathbf{R}$ & $\mathbf{R}^{2}$ & $\mathbf{R}^{2}$ Change & b & Beta & F-Value & $\mathbf{P}$ \\
\hline Student overall score & 0.80 & 0.63 & 0.63 & 0.60 & 0.54 & 61.45 & 0.001 \\
\hline Science Score & 0.82 & 0.67 & 0.30 & 0.30 & 0.30 & 19.57 & 0.001 \\
\hline Constant & & & & 2.50 & & & \\
\hline
\end{tabular}

Adjust $\mathrm{R}^{2}=0.65$

\section{Conclusions and Recommendations}

The study shows that the performance of Secondary School Students in Agriculture can be explained by student overall grade, and science grade. This implied that science, and even mathematics should be studied together with agriculture at the secondary and high school level, to enable those students who may wish to major in agriculture at the tertiary level to possess adequate background. This was corroborated by Dlamini (1995) who found out in his work- the relationship between Home and School related factors and the performance of student in Agriculture in Malawi that there exist a strong relationship between students' performance in agriculture and such variables as science score, overall score and mathematics. 
Another implication of this study is that entry requirement to study agriculture at tertiary institutions must include science: Mathematics and overall performance upon completing senior secondary school.

Secondly, the study also revealed moderate to low relationships among the home and school related factors, and the performance of secondary school students. This implies that while certain home and school related factors have certain influence (moderate) on performance of secondary school students in agriculture, factors with low relationship has very negligent effect on performance of secondary students in agriculture.

It is therefore recommended that science; mathematics and overall performance of student should be considered when counseling pupils to take agricultural science at senior secondary level and in matters related to admissions to study agriculture at tertiary institution.

\section{References}

Blustein, D.L. (1986). Identifying Predictors of Academic Performance of Community College Students. Journal of College Student Personnel, 27(3), 242-249.

Davis, J.A. (1971). Elementary Survey Analysis. Practice Hall, New Jersey.

Dispensier, A. (1971). College Performance of Disadvantaged Students as a Function of Ability and Personality. Journal of Counselling Psychology, 18(3), 298-305.

Dlamini, B.D. (1995). The Relationship between Home and School related Factors and the Performance of Student in Agriculture in Malawi. Journal of Agricultural Education Extension, 2(1), 59-64.

Duke, D.G. and Duke, J.R. (1990). Predictor of Performance on the Mathematics test of The Professional Skills Test. Arkansas: Harding University of Searcy.

Faleye, B.A. and Afolabi, E. (2005). The Predictive Validity of Osun State Junior Secondary Certificate Examination. Electronic Journal of Research in Educational Psychology. $5,3(1), 131-144$

Goodday, D.O.M. (1974). The School Agriculture Pilot Project in Swaziland. Journal of Educational Development International, 2(2), 94-98.

Larose, S. and Roland, R. (1991). The Role of Prior Academic Performance and NonAcademic Attributes in the Prediction of the Succors of High-risk College Students. Journal of College Student Development, 32(2), 17 - 177. 
Ojelade, A.Y.P. (2004). Relationship of Entry Qualification and Continuous Assessment on Final Academic Performance of Agricultural Education Students. AJOVED 3(1), 77 86.

Olowa, O.W. (2002). Facilities and Academic Achievement of Student in the Study of Agricultural Science in Selected Secondary Schools of Ondo State. A Paper Prevented at the School of Education Seminar Series F.C.E (T) Akoka, June 2002.

Oluwole, Y.A. (1985). Self-Sufficiency in Food Production and the Changing Curriculum in Agricultural Education in Nigeria. Association for Agricultural Education held at the I.A.R. and T, Moor Plantation, Ibadan. 